\title{
Humour expression at the crossroads of deaf and hearing cultures: the case of the Oral Deaf fitted with cochlear implants
}

\author{
Laurence Vincent-Durroux \\ Université Grenoble Alpes, LIDILEM, France \\ laurence.durroux@univ-grenoble-alpes.fr
}

\begin{abstract}
In deaf people who use sign languages, humour expression has been looked at extensively, examining the preferred means and topics in deaf humour (Cancio-Bello 2015; Sutton-Spence \& Napoli 2009). Humour expression remained to be further examined in deaf people with cochlear implants, which give access to the sounds of speech, and facilitate speech production and interaction. In this paper, we address these questions: is delayed linguistic input an obstacle on their way to using humour expression in their target spoken language? To what extent do profoundly deaf cochlear implants recipients access and share the means and topics of hearing people? How do they stand culture-wise? We analyze French and English data collected from 18 profoundly deaf cochlear implant recipients, aged two to 15, with ages at implantation varying from one to 7 , and filmed in interaction with an adult. For the youngest children, the main sources of humour are the gestures they make, the objects they build, and onomatopoeia. Older children use formal speech in order to make the adult laugh, either by taking up the adult's speech, or by speaking to / for the objects they have built. The children tend to grow out of deaf experience jokes and visual jokes. They already evidence some of the trends of humour in their respective target language (e.g. third-party target in French, discursive strategies in English), although the French participants do not use linguistic play as much as would be expected, and the English participants do not use much recipient-oriented humour. We discuss the growing ability of cochlear implant recipients to access speech-based, co-constructed humour, even though such high-level linguistic processes have been shown to be impacted in deaf children (Arfé et al. 2015; Bourdin 2015) with deafness itself and limited linguistic input as possible causes accounting for their preference for discursive strategies over play-on-words in humour expression.
\end{abstract}

Keywords: profound deafness, cochlear implant, humour, English, French. 


\section{Introduction}

In deaf ${ }^{1}$ people who use sign languages, humour expression has been looked at extensively, to examine the preferred means (e.g. puns on similar looking signs) and topics (e.g. deafness) of deaf humour (Cancio-Bello 2015; Sanders 1986; Sutton-Spence \& Napoli 2009; Sutton-Spence \& Napoli 2012; Bienvenu 1994). But little is known about humour expression in deaf people who use an oral language (they are usually referred to as the Oral Deaf). Humour has been found to be very difficult to deal with for those who had poor hearing benefit through analog hearing aids (Vincent-Durroux 2014) but remains to be further examined in deaf people with cochlear implants, devices which give access to the sounds of speech, and facilitate speech production and interaction. Humour in children with moderate to severe deafness has been studied by Nwokah, Burnette \& Graves (2013). Yet, for children with profound deafness from birth, linguistic input is delayed; is this an obstacle on their way to understanding and using the specific humour in the target spoken language? Are profoundly deaf cochlear implant recipients more likely to share Deaf humour or do they bridge the gap and access the means (e.g. puns and riddles) and topics (such as incongruous situations) of humour in hearing people? Are certain aspects of humour more difficult for them to access?

To try and answer these questions, we considered data collected from 18 French and English profoundly deaf cochlear implant recipients, aged two to 15 , filmed in interaction with an adult. In passages that involve laughter and humour (Charaudeau 2006), we characterized the means and topics that led the participants to laugh together. In this paper, we report our research questions and hypotheses, the methods we used to test them, and we discuss the main results of our analyses.

\section{Research questions and hypotheses}

\subsection{Deafness and language}

When profound deafness is diagnosed in their child, parents may choose to learn the sign language in use where they live (British Sign Language, American Sign Language, French Sign Language, etc.) in order to communicate with their child as soon as possible, even if the linguistic input is limited and delayed, contrary to the case of deaf children who have deaf parents and sign language as their mother tongue (3-4\% of deaf children). Parents may also choose oral speech to communicate with their child, who becomes an "Oral Deaf". This implies fitting the child with hearing aids. Digital hearing aids, and cochlear implants when the child is eligible, can now provide access to the frequencies and volume of human speech. With deafness being now diagnosed very early (within a few days after birth), cochlear implants can be fitted as early as six months, i.e. within the phonological critical period spanning from the sixth month of fetal life to 12 months of chronological age. Sign languages are therefore not as crucial to start early communication as they once were, when little benefit was to be expected from analog hearing aids. ${ }^{2}$

Yet, even after several years of cochlear implant use, a proportion of children demonstrate "language deficits, even though none of the children had other disabilities and all had received intensive rehabilitation" (Duchesne, Sutton \& Bergeron 2009). If "some children with a CI [cochlear implant] attained language levels on a par with hearing similar-age peers, more

\footnotetext{
${ }^{1}$ Contrary to "deaf", which refers to the hearing status, the word "Deaf" with a capital letter, is used to refer to people who identify as culturally deaf, in particular through their choice of a language (e.g. the Oral Deaf).

${ }^{2}$ Bilingualism (signs and speech) is chosen in families with several deaf children or with specific links with the deaf community.
} 
frequently, however, a language delay is still present despite a normal, near-normal, or accelerated rate of language growth over time" (Hallé \& Duchesne 2015).

The impact of sensory deprivation from birth (e.g. profound deafness) is likely to imply differences in cognitive patterns with possible consequences on cognitive-related academic outcomes (such as reading, mathematics, achievement scores, and problem solving, Marschark et al. to appear) and on language acquisition (Vincent-Durroux 2014). Indeed, the Oral Deaf's speech evidences (1) common syntactic and semantic deviant features in different spoken languages (English and French), (2) striking similarities with features of sign languages, although the deaf speakers who provided the data did not know sign languages (VincentDurroux 1992; Vincent-Durroux 2009a): for example, articles and prepositions are used in similar ways in the Oral Deaf's speech and in sign languages, hinting at differences in the conception of time and space between deaf and hearing people (Vincent-Durroux 2009a; Vincent-Durroux 2014). The study of spontaneous speech from 20 Oral Deaf English and French teenagers demonstrated the existence of Oral Deaf Languages (Vincent-Durroux 2009a) and expanded previous claims based on written data in English ("Deaf English", Charrow 1975) and in French ("l'écriture sourde" [Deaf writing], Lacerte 1988).

\subsection{Definition of humour and description of the stages towards adult humour}

Humour can be defined in many ways, since cognitive, social, and emotional dimensions factors can be taken into account. For example, humour can be seen as having a social function, as people will laugh thirty times more frequently in social than in solitary situations (Provine \& Fischer 1989) or as an approach to life according to the Danish philosopher Høffding. Also, humour can be either spontaneous (e.g. play-on-words) or pre-constructed (e.g. jokes and riddles), and can be expressed in various forms (e.g. visual and physical forms, such as practical jokes, funny faces, exaggerated gestures, unusual performance; spoken forms, such as jokes and retelling of humorous events; pictorial forms, such as picture cartoons. For a review, see Nwokah, Burnette \& Graves 2013).

In this paper, we will concentrate on two forms of humour in spontaneous sequences: the spoken form, as a part of our current study on the speech of the Oral Deaf (see 3.1., below), and the visual form, since some of the participants are very young and may have limited access to speech. We will consider that basically, humour "is play" (Cunningham 2005: 94). "Play" is to be understood in several ways: (1) humour is amusing (Holmes \& Marra 2002: 67); (2) it involves some mismatch or play between two representations (i.e. "expected and presented stimuli", Vrticka, Black \& Reiss 2013: 1) causing incongruity. Therefore humour is about "detecting and [sometimes] resolving incongruity" (ibid.); (3) humour results from a "game" between the actors of the situation of communication ("Comme tout acte de langage, l'acte humoristique est la résultante du " jeu » qui s'établit entre les partenaires de la situation de communication et les protagonistes de la situation d'énonciation": "like any speech act, humorous acts result from a 'game' between the partners in the situation of communication and its protagonists”, Charaudeau \& Maingueneau 2002, quoted by Charaudeau 2006: 22).

To look at children's humour at various ages, we have chosen a stage-model that is widely used, being one of the rare models that have not underestimated children's early capacities regarding understanding, sharing, and producing humour (Del Ré et al., this volume). According to McGhee's stage-model of children's humour (McGhee 1979; McGhee 2002), children go through four stages, each stage dealing with incongruity in a specific way, as mentioned by Cunningham (2005: 104):

a child progresses from being able to perceive incongruity in infancy [before 2 years] (stage 1) to producing incongruity nonverbally in toddlerhood [2-3 years] (stage 2), to producing incongruity verbally in early childhood [4-5 years] (stage 3). Also as we have seen, incongruity in early 
childhood often means being silly. In the elementary school years [6-10 years], the silly quality of humor gradually gives way as children see humor as involving more than what is nonsensical. By stage 4, the final stage in McGhee's model, the "mature" humorist begins to prefer humor that presents not only an incongruity but also a resolution to the incongruity. (our underlining)

These findings will be crucial for our analysis of humour in children and teenagers fitted with cochlear implants, along with the description of the trends in the languages under consideration (Table 1).

They will nicely fit to the definition of humour adopted here, i.e. a speech act that involves play and incongruity.

\subsection{Deaf culture and Deaf humour}

The macroconcept of "languaculture" has recently emerged, i.e. the notion that language and culture have to be looked at together because they are intertwined (Horejes 2012). As mentioned above, the Oral Deaf's speech has characteristics of both their target spoken language and sign languages. We may then suggest, if language and culture are intertwined, that shared linguistic features may evoke the fact that the Oral Deaf share two cultures, Deaf and oral cultures. When it comes to humour, which is an expression of culture, how do the Oral Deaf access the various aspects of humour: do they compare with Deaf humour and/or with humour as practised in the oral language they use?

Deaf culture has been described in many papers (e.g. Leigh et al. 2018) and Deaf humour has been thoroughly looked at in sign languages (Cancio-Bello 2015; Sanders 1986; SuttonSpence \& Napoli 2009; Sutton-Spence \& Napoli 2012). Cancio-Bello (2015) describes two main categories of jokes: Deaf experience jokes and (sign) language-related jokes. As concerns language-related jokes, humour is mostly based on the visual nature of sign languages, with "the creation of new visual signs", and "witty reanalysis of existing signs". It is mostly third-party oriented, with "out-group people" as a target (Sutton-Spence \& Napoli 2012).

\subsection{Humour in spoken languages}

In this paper, we compare data in two spoken languages (French and English) in order to find whether features (that are possibly deafness-related) appear whatever the target language and to what extent the data conforms to humour in the target spoken language. Therefore, Béal and Mullan's model of analysis (Table 3, below) and their recent studies comparing humour in French and in (Australian) English will be crucial (Béal \& Mullan 2013; Béal \& Mullan 2017; Mullan \& Béal 2018). According to Béal and Mullan (2013), the main distinctive features which appear between (Australian) English and French conversational humour in adults are as follows:

- the Australian English produce more recipient-oriented humour and they threaten the other's face, whereas the French prefer humour at the expense of a third-party;

- the French have a clear preference for linguistic play while the Australian English prefer incongruous images and fantasy, grouped under the label "discursive devices" by Béal and Mullan (2013).

Even if distinctive traits between various English-speaking communities have been investigated, Béal (2010: 78-81) establishes that Australian, British, and American conversational features are widely shared and constitute an aspect of the Anglo-Saxon culture; according to Béal, there are more common points between them than with the French conversational style. This is why, due to the lack of studies actually comparing British English to French, the results obtained by these authors on humour are still of interest for this study.

Table 1 summarizes the trends of adult humour in terms of topics, targets, and devices, which will serve as reference points for our study for the following reasons: the fact that the 
authors compared the same features of humour across the languages involved in our study is of great methodological interest; adult speech is the Oral Deaf's goal; major recent usage-based studies on language development in children (e.g. Tomasello 2003; Morgenstern \& Parisse 2017, on English and French respectively) have not provided characterization of humour. This will be taken in consideration when discussing our own results.

Table 1. Trends (filled zones) in humour: topics, targets and devices

\begin{tabular}{|c|c|c|c|}
\hline & $\begin{array}{c}\text { Sign } \\
\text { languages }\end{array}$ & $\begin{array}{l}\text { Spoken } \\
\text { French }\end{array}$ & $\begin{array}{l}\text { Spoken } \\
\text { English }\end{array}$ \\
\hline \multicolumn{4}{|l|}{$\begin{array}{c}\text { Deaf } \\
\text { experience }\end{array}$} \\
\hline \multicolumn{4}{|l|}{ Visual jokes } \\
\hline \multicolumn{4}{|l|}{$\begin{array}{l}3_{w}^{f d} \text { party } \\
\text { oriented }\end{array}$} \\
\hline \multicolumn{4}{|l|}{$\begin{array}{l}\text { Recipient- } \\
\text { oriented }\end{array}$} \\
\hline \multicolumn{4}{|l|}{ Face threat } \\
\hline \multicolumn{4}{|l|}{ Linguistic play } \\
\hline$\frac{\text { Discursive }}{\text { devices }}$ & & & \\
\hline
\end{tabular}

The Oral Deaf and Deaf Signers share deafness. Therefore, do they also share Deaf experience jokes and a preference for third-party oriented jokes? Or do the Oral Deaf conform to the characteristics of humour observed in spoken languages communities, which would mean that they fully master speech features? Is good, early access to oral conversation thanks to cochlear implants sufficient to help deaf children access the features of humour in their target spoken language? If not, to what extent do they develop this capacity? And on which topics more specifically? Are some of the means used in humour easier for them to use? To try and answer some of these questions, we will examine humour in the speech of profoundly deaf children and teenagers.

\section{Methods}

\subsection{The data}

Our study is based on spoken data collected for the general purpose of describing speech in the Oral Deaf. The current study includes 18 profoundly deaf children and teenagers fitted with cochlear implants: nine of them speak English, nine of them speak French. When they were recorded, they were aged from two to 15 , with ages at implantation varying from one to 7 . The data was collected in France and in the United Kingdom between 2006 and 2018. The teenagers were audio-recorded once each, for a comparative study, with and without cochlear implants. 
The children were filmed several times each, for an on-going research project (DEL-Deafness, Early implantation, Language, IRB00010290-2019-01-29-55) on their linguistic development in the first years after early cochlear implantation.

Each session lasted for about 40 minutes. The tasks were adapted to the age of the participants: the teenagers engaged in debates, in story-telling, and narratives, while the younger participants were given toys to play with their parents. In all contexts, the subjects were interacting with an adult. The recordings were transcribed by the author, and the transcriptions were checked by an undergraduate student. They followed ICOR transcription norms ${ }^{3}$, in which laughter is taken into account. Recognizing laughter in the recordings was not a problem, since laughter is basically similar in deaf and hearing people, with a tendency to lower amplitude and extended duration in deaf people (Makagon, Sumie Funayama \& Owren 2008). According to Partington (2006), laughter is an interactional communicative phenomenon which may have various causes, such as nervousness, fear, and of course humour. Laughter and humour often go together, although humour does not necessarily entail laughter (Charaudeau 2006: 20). But according to Del Ré, Dodane \& Morgenstern (2015: 136-137), contrary to adults who have better control over themselves, children almost always laugh in humourous situations. In our data, we therefore looked at the sequences in which laughter was noted in the transcripts, then selected those which evidenced amusement from at least one of the participants, following Holmes and Marra's definition of conversational humour ("utterances [...] perceived to be amusing by at least some of the participants", Holmes \& Marra 2002: 67). The selection thus amounted to 36 sequences (16 in French, 20 in English).

\subsection{The subjects}

The 18 subjects involved in this study had prelingual bilateral profound deafness and were fitted with cochlear implants. They had typical aided thresholds through the implant system of $30 \mathrm{~dB}$ across the speech frequencies and had no sign language in their environment. Among the nine speakers of English, four of them had had early implantation (before 24 months), which is also the case of four out of the nine speakers of French. Table 2 provides the details of the subjects: code, gender, target language, year of birth, age at implantation, age at recordings (i.e. chronological age), hearing experience when recorded (i.e. hearing age).

\footnotetext{
${ }^{3}$ http://icar.univ-lyon2.fr/projets/corinte/documents/2013_Conv_ICOR_250313.pdf
} 
Table 2. Details of the subjects involved in the study

\begin{tabular}{|c|c|c|c|c|}
\hline $\begin{array}{c}\text { Code } \\
\text { Boy or girl } \\
\text { Language }\end{array}$ & $\begin{array}{c}\text { Year of } \\
\text { Birth }\end{array}$ & $\begin{array}{c}\text { Age at implantation } \\
\text { (in months - M) }\end{array}$ & $\begin{array}{c}\text { Age at } \\
\text { recordings (M) }\end{array}$ & $\begin{array}{c}\text { Hearing } \\
\text { experience (M) }\end{array}$ \\
\hline AF, boy, Eng. & 2015 & 14 & $33 ; 37 ; 42$ & $19,23,28$ \\
\hline TD, boy, Eng. & 2014 & 13 & $39 ; 43 ; 48$ & $26 ; 30 ; 35$ \\
\hline HR, boy, Eng. & 2014 & 17 & $38 ; 42 ; 47$ & $21 ; 25 ; 30$ \\
\hline AM, boy, Eng. & 1996 & 24 & 120 & 96 \\
\hline AX, boy, Eng. & 1995 & 36 & 132 & 96 \\
\hline BL, boy, Eng. & 1995 & 36 & 132 & 96 \\
\hline SR, girl, Eng. & 1991 & 48 & 180 & 132 \\
\hline EB, girl, Eng. & 1992 & 36 & 168 & 132 \\
\hline LS, girl, Eng. & 1992 & 60 & 168 & 108 \\
\hline TH, boy, Fr. & 2015 & 12 & $28 ; 32$ & $16 ; 20$ \\
\hline M, girl, Fr. & 2010 & 18 & $49 ; 54$ & $30 ; 36$ \\
\hline R, boy, Fr. & 2011 & 13 & $30 ; 49$ & $30 ; 36$ \\
\hline SM, girl, Fr. & 1996 & 36 & 120 & 84 \\
\hline MR, girl, Fr. & 1995 & 36 & 132 & 96 \\
\hline CT, girl, Fr. & 1994 & 36 & 120 & 108 \\
\hline TM, boy, Fr. & 1993 & 24 & 156 & 132 \\
\hline GP, boy, Fr. & 1992 & 60 & 168 & 108 \\
\hline CL, girl, Fr. & 1991 & 60 & 180 & 120 \\
\hline
\end{tabular}


Figure 1 illustrates how the English and the French subjects matched at recordings.

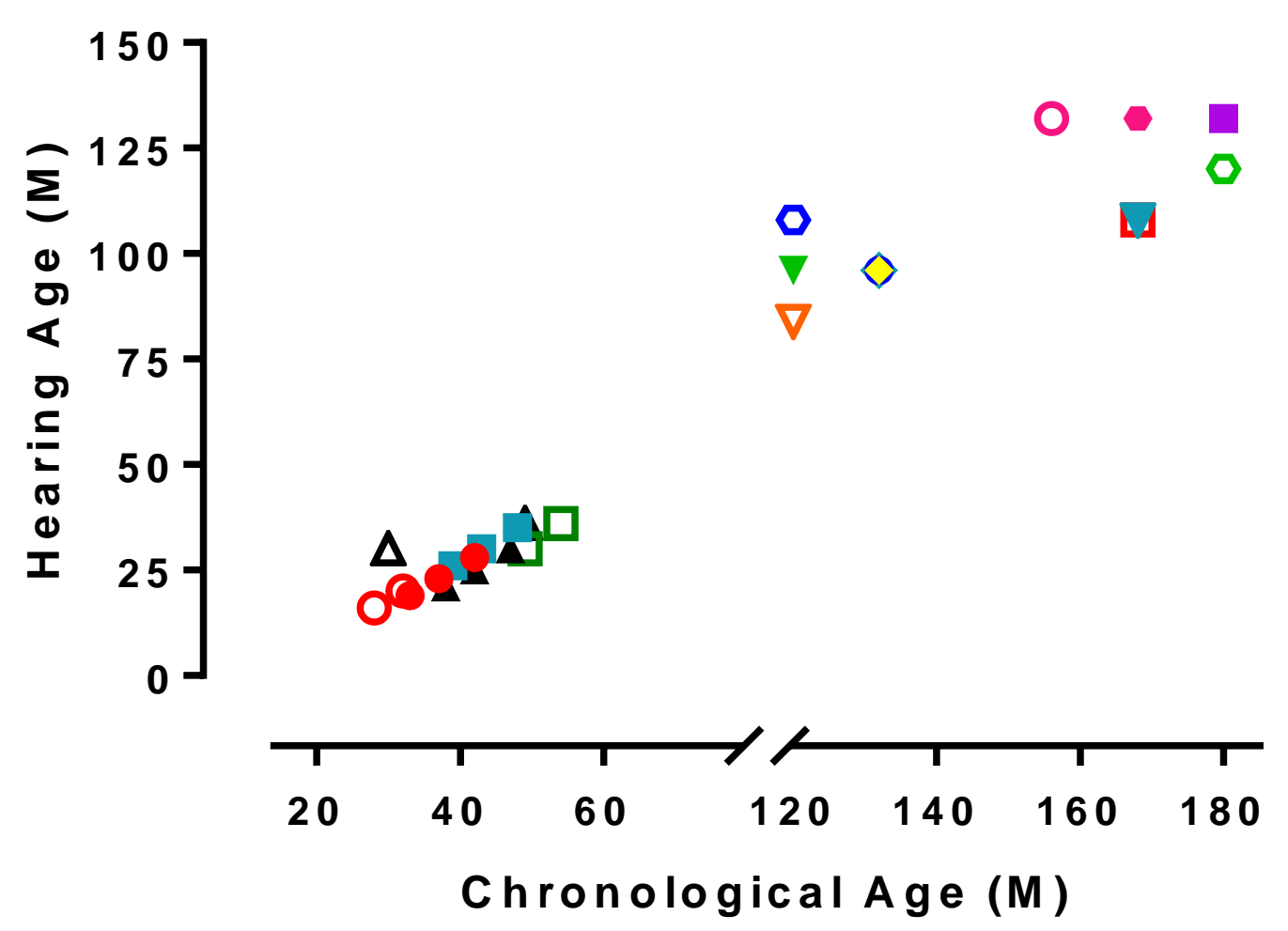

Figure 1. Chronological and hearing ages (in months - M) at recordings.

Filled symbols: speakers of English. Empty symbols: speakers of French. Each shape represents a different speaker.

Two subgroups clearly appear:

- A subgroup with children who have mean auditory experience duration (thanks to cochlear implants) of 27 months, and mean age at recordings of 41 months. They are likely to master stage 2 (i.e. non-verbal incongruity) and possibly stage 3 (i.e. verbal incongruity) in McGhee's stage-model, since children with early cochlear implantation may perform as well as hearing children in some linguistic capacities (Hallé \& Duchesne 2015). In more recent studies, Del Ré, Dodane \& Morgenstern (2015) and Del Ré, Dodane, Vieira, LeroyCollombel \& Morgenstern (this volume), found that at 28-30 months, children with typical development do combine the 6 criteria that are necessary to engage in humour: the recipient laughs or smiles; there is a discourse-embedded relation ("relation entre la situation et l'énoncé ou encore, entre deux énoncés produits par deux locuteurs différents ou par le même locuteur à partir du moment où les interlocuteurs deviennent complices dans le dialogue" - "relation between the situation and the utterance, or between two utterances produced by two different speakers or by the same speaker, once the co-speakers have initiated a rapport"); connection or shared knowledge; incongruity; joint attention; capacity of initiating humour.

- Another subgroup with teenagers who have had at least 84 months' hearing experience; they compare in that respect to children with typical development who, after seven years, 
evidence good logical capacity and access the polysemy of words (McGhee 1979; McGhee 2002).

When we look at the selected sequences, we find that almost all of them have been produced by the children in the younger group, with only two out of 36 sequences being produced by the implanted teenagers.

\subsection{Analysis framework}

To analyse humour in the selected sequences, we followed Mullan and Béal's model (2013; 2017), which is most adequate for this study as it has been designed from French and English data, and examines several dimensions of humour. This four-dimensional model takes into account (1) the interplay between the speaker, the target and the recipient; (2) how the language is used to achieve humour, either by playing with its forms (linguistic play) or with its capacity of reference; (3) its pragmatics, i.e. the intention and consequence of humour; (4) at which stage humour occurs in the interaction. The four dimensions of analysis and the items to be looked at in each dimension can be summarized as follows (Table 3).

Table 3. Humour analysis: Béal \& Mullan's four-dimensional model

\section{The speaker/target/recipient interplay}

- self-oriented

- recipient-oriented

- third-party oriented

- non-specific target

\section{The language dimension}

- linguistic play: e.g. play-on-words, play on sounds of words, putting on an accent or a funny voice; borrowing words from other languages; exaggeration and understatement

- discursive strategies: e.g. implicit references; incongruous images/situations; personification of plant, animal, or inanimate object; distortion of reality (of selfimage, situation, participants); internal logic (fantasy or absurd humour with escalation, collaborative scenarios)

\section{The different pragmatic functions}

- e.g.: creating a bond/connection with other participants

- promoting egalitarianism and not "big-noting" oneself

- face concerns (humour that threatens the other's face; humour used to repair real or potential threat; humour in self-defence to a perceived face threat)

\section{The interactional dimension}

- response to a previous turn (2nd turn of an adjacency pair)

- initiated in a first turn + ensuing responses

- construction of a collaborative humorous scenario (fantasy humour) 


\section{Analyses of the data}

\subsection{The speaker/target/recipient interplay}

Following Charaudeau (2006: 22), we consider that humour is a speech act involving three protagonists: the speaker, the recipient, and the target. According to Béal \& Mullan, the target of humour can be self-oriented, recipient-oriented, third-party oriented, or have a non-specific target.

Table 4 provides the results in terms of targets in the sequences when humour is initiated by the deaf speakers ( 32 sequences out of the 36 under consideration).

Table 4. Targets when humour is initiated by the deaf speakers

\begin{tabular}{|c|c|c|c|}
\hline Target & French sequences & English sequences & Total \\
\hline Self-oriented & 1 & 0 & 1 \\
\hline Recipient-oriented & 1 & 1 & 2 \\
\hline Third-party oriented & 5 & 11 & 16 \\
\hline Non_specific target & 6 & 7 & 13 \\
\hline
\end{tabular}

When we look in detail at the 36 sequences of humour in our data, we find that:

- Humour is clearly self-oriented in only one sequence (example 1): GP, a French teenager, mocks himself after giving a high price for a fare which should have been cheap as it was meant to convince the recipient that the teenager could manage a trip to Italy:

(1) en avion (...) c'est quoi le prix Internet prix avion pour l'Italie ouai huit cent soixante quinze euro euh ouai bon on verra bien hein (by plane / what is the price / Internet cost plane to Italy / well 875 euro / hum well then we'll see that huh (laughter)) (GP)

- Humour is rarely (six sequences) recipient-oriented, with only two sequences (examples 2 and 3) initiated by the children, one in English, one in French, as they address a toy:

(2) $\left[\mathrm{oh} \mathrm{shshsh}{ }^{4}\right.$

wake up

[no (laughter) he's asleep shshsh

wake up

[that's not very oh who is it there (HR)

(3) il tire la langue (he is sticking out his tongue)

[oh le coquin il faut pas tirer la langue] (oh this is mischievous one shouldn't stick out one's tongue)

monsieur patate il faut pas tirer la langue (mister potato one/you shouldn't stick out one's/your tongue) $(\mathrm{M})$

- Humour is mostly third-party oriented (16 sequences: eleven in English, which is remarkable, and five in French): the targets are mostly the toys built by the children, especially Mr Potato Head ${ }^{\mathrm{TM}}$ (example 4) and on one occasion, the child's brother (example $5)$ :

\footnotetext{
${ }^{4}$ The symbol [ stands at the beginning of adults' speech.
} 
(4) [I think that's his feet

(laughter) hat it's his hat

[it's his hat

it doesn't fit on very well

(...)

there $\mathrm{X}$ he looks funny

[he does look funny what a silly man he says no

(laughter) (TD)

(5) [what does A. say to HR

I don't want nothing [...] I don't want my dinner with HR

[(laughter) that's naughty isn't it (HR)

It is remarkable that the deaf English speakers highly favour third-party oriented humour, contrary to what has been observed in adults' spoken English (Table 1). This will be taken up in the Discussion Section.

- Humour is often not directed at a specific target (13 sequences: seven in English and six in French). In this category, humour applies to events that happen during the interaction, such as the falling of objects from the table (six sequences; example 6), which leads to repeated onomatopoeia (e.g. boum badaboum) and laughter; hilarious scenarios also belong to this category with incongruous developments in the game that is being played, by treating an object as a different object, which corresponds to stage 2 (producing incongruity non verbally) in McGhee's stage-model (example 7). More details will be given in the Section dedicated to discursive strategies (4.2.2.).

(6) ah ah (ha ha)

[qu'est-ce qui y'a (what's going on)

poum patapoum (onomatopeia: poum patapoum)

[patapoum c'est dur (patapoum it's hard)

ah pataboum ah (ha pataboum ha) $(\mathrm{TH})$

(7) [we can fly together where shall we go

bird road

[bird road (laughter) (HR)

\subsection{The language dimension}

In Béal and Mullan's model, the language dimension includes linguistic play and discursive strategies. Linguistic play refers to sequences in which the language forms are played upon, as in play-on-words and play on the sounds of words, whereas discursive strategies are about using the language for its referential capacity (Table 3). These features may correspond to stages 3 and 4 in McGhee's stage-model.

In our data, as shown in Table 5, there are more sequences (22) involving discursive strategies than sequences involving linguistic play (13), with very few play-on-words in the latter category. It can also be noticed that incongruity in isolation (incongruous items: 15) appears more frequently than scenarios based on internal logic (7), exemplifying the difficulty of deaf children to deal with sequential events (Bourdin 2015). 
Table 5. The language dimension

\begin{tabular}{|c|c|c|c|}
\hline Dimension & French sequences & English sequences & Total \\
\hline $\begin{array}{c}\text { Linguistic play: play-on- } \\
\text { words }\end{array}$ & 1 & 1 & 2 \\
\hline $\begin{array}{c}\text { Linguistic play: } \\
\text { play on the sounds of } \\
\text { words }\end{array}$ & 5 & 2 & 7 \\
\hline $\begin{array}{c}\text { Linguistic play: } \\
\text { understatement }\end{array}$ & 0 & 4 & 4 \\
\hline Linguistic play: total & 6 & 7 & 13 \\
\hline $\begin{array}{c}\text { Discursive strategies: } \\
\text { internal logic }\end{array}$ & 4 & 3 & 15 \\
\hline $\begin{array}{c}\text { Discursive strategies: } \\
\text { incongruous items }\end{array}$ & 5 & 10 & 22 \\
\hline Discursive strategies: total & 9 & 13 & \\
\hline
\end{tabular}

\subsubsection{Linguistic play}

Among the various possibilities of linguistic play, we only found play-on-words, play on the sounds of words, and understatement. We expected few play-on-words as difficulties have been evidenced (Dutilleul-Guerroudj 2005) in deaf children with words that have several meanings (e.g. basket: shopping basket / wastepaper basket / laundry or clothes basket / picnic basket / fruit basket). Deaf children usually understand the prototypical value of the word but not its other meanings. This could be part of the "linguistic deficits" and "language delay" reported in deaf children at a later age although their lexicon has developed as fast as in typical children (Duchesne et al. 2009; Hallé \& Duchesne 2015). As expected, we found very few (two) occurrences of play-on-words, both provided by the older group (examples 8 and 9):

(8) I was hoping there'd be a big present on the table which was a big present hum I got an i-pod speakers (LS)

(9) il y a pas de tour à exploser là-bas t'inquiète ah non ouai il y a Pise (there is no tower there don't worry don't worry oh no yeah there's Pisa) (GP)

In example (8), the play-on-word is on BIG, which means LARGE in the first instance and EXPENSIVE in the second. In example (9), the play-on-word is on (French) TOUR (tower), which can refer both to skyscrapers (which run the risk of an explosion) and to old stone towers, as in Pisa, where the speaker considers an explosion whereas we all know it is likely to collapse rather.

Playing on the sounds of words is made obvious when the speaker repeats the same words several times. It occurs when the youngest child repeatedly uses onomatopoeia as in examples 10-11:

(10) [tu veux que je la monte alors tu me donnes une roue tu es mon assistant je peux avoir une roue merci assistant mmmm tu me donnes une deuxième roue oh (do you want me to put it on then you give me a wheel you are my assistant can I have a wheel thank you assistant mmmm you give me another wheel ho)

badaboum encore badaboum (badaboum again badaboum) 
[encore badaboum c'est tombé de nouveau (again badaboum it has fallen again) badaboum ça c'est pour faire quoi (badaboum what is this for) (TH)

(11) je fais une maison avec une fe- une mais-par terre (I am building a house with a wi- a hou- on the floor)

[tu mets par terre tu fais une maison avec quoi TH une maison avec un toit (you put it on the floor you are building a house with what $\mathrm{TH}$ a house with a roof)

une maison avec un toit badaboum $x$ un toit (a house with a roof badaboum $\mathrm{x}$ a roof) (TH)

Playing on the sounds of words also occurs when chunks of words with similar sounds are repeated. This is done by only one child, with the repetition of [g] (WRONG ISLAND AGAIN) and of [t] (SPIT IT OUT): the first chunk is repeated eight times (example 12) and the second chunk is repeated seven times in a short sequence (see example 25 below):

(12) [are they on the XX island

it is the wrong island

[this is the wrong island again

yeah

[not again

they went why they went to the wrong island again

[they're not reading their map properly are they

(laughter) why

[they are they are being silly

he don't know that he is XXXX / in park this is at the right island

[this is the right island

yeah

[do they have to dig dig dig for the treasure

dig dig dig dig dig dig with their head

[with their heads you don't dig with your head

(laughter)

dig dig dig dig dig dig dig dig we found the treasure

[yeah what is the treasure

gold magic

[gold and magic

oh that X it's a cat he does look XXXX cat oh it's just a cat

[it's just a cat

meeeou they found the wrong island again they found the wrong island again

[oh they found the wrong one again

yeah

[try again where are they going now

in the wrong island teedee that's the wrong island where is the right island

[that one (TD)

Understatement is found, but only in the English teenagers' data and on rare occasions (four sequences, examples 13-16):

(13) he got milk and and breakfast stuff and medicines because I think he's not feeling very well (AX) 
(14) [what would you think if your brother Leo went with you to look after you] yeah [don't you think it would be better] hum well but my friends haven't really invited Leo (AX)

(15) [well yes or maybe you could go with your sister]

no I don't want to have my sister

[why]

because she because she don't know my old friend very much and I don't think she will enjoy herself because we'll be talking a lot but she won't know the conversation (EB)

(16) come on my friend is so delighted to anyway it's not dangerous to I mean (...) it's a bit harsh on me (AM)

It is interesting to notice that the target of understatement is mainly third-party oriented and doesn't relate to Deaf experience but bears on general feelings, whereas in a previous study on deaf teenagers with analog hearing aids (Vincent-Durroux 2009b), we found that euphemism was always self-oriented and related to Deaf experience.

Playing on the register can be seen as linguistic play and a form of humour (Charaudeau 2006). In our data, we find two such occurrences, with young children borrowing the phrases and the tone from their parents: "we'll be right back" and "oh dear" (examples 17-18):

(17) [TD you need the toilet

yeah

[we'll go

oh mummy (to the experimenter) we'll be right back

(laughter)

[ok

(laughter)

we'll be right back (...) tidy it up

(laughter)

(18) oh where you want to put it $\mathrm{mm}$ oh dear

oh dear

(laughter)

\subsubsection{Discursive strategies}

Among the various possibilities of discursive strategies that are likely to convey humour (Table 3 ), we only found internal logic with escalation of fantasy, and incongruity.

Thanks to internal logic, escalation of fantasy was a frequent scenario, mainly related to construction toys: the children imagined a zoo, a hospital, treasure islands... In this context, it is not surprising to find discursive strategies that allow the scenario to become amusing. Examples 7 and 12 (above) are good examples: the first sequence is about making a bird which eventually flies to bird road; the second sequence is about being unable to read a map and getting to the wrong island while looking for a treasure.

Incongruous developments are to be related to the children's imagination in occurrences such as examples 19-21, where we can notice that the mother repeats the incongruous expressions to make sure she has understood properly; in example 21, we notice the personification of an animal: 
(19) [try again where are they going now

in the wrong island teedee that's the wrong island where is the right island

[that one

XXXXXXXX thunder and lightning

[on the thunder and lightning

yeah

[mmm waoo (TD)

(20) [where is he going

on in a tchu tchu train

[he's going on a tchu tchu train where to

he going on a tchu tchu train and / em he is going on the track

[XX on the track (laughter) no that would be very dangerous

yeah

[you don't go on a track bye bye (HR)

(21) he's got a steering-wheel

[who has got a steering-wheel

the giraffe

(rires) (TD)

The production of incongruity may resort to the multimodal dimension of language via speech, body actions and gestures:

(22) [where's his nose that's his hand where's his nose there look that's his eyes his nose where's AF's nose

that

[oh what have we got now

th- / X

[(laughter) I don't think they are for AF I think they are for him for $\mathrm{AF}(\mathrm{AF})$

(23) [it's a magnet oh that's clever isn't it oh no (laughter) no no not on your hair I get magnet

[yeah but you don't put it on your hair it's the same clever

I can put it on the ear

[yeah but it's not it's not the same oop (HR)

The latter occurrence clearly points at the incongruous use of a magnetic toy as if it were the magnetic part of the cochlear implant; here humour is based on Deaf experience.

\subsection{The different pragmatic functions}

In our data, humour has two pragmatic functions: creating a rapport between the speakers, and training for face concerns.

The creation of a connection between adult and child is obvious when they build scenarios together: this involves taking speech turns and play turns, for example when parent and child add alternately an item to Mr Potato's head, in order to make it look as funny as possible. It is also the case when one child speaks for his brother and alludes to their arguments at home. 
Face concerns do not appear as such: humour is not used to threaten the other speaker's face or in self-defence to a perceived face threat, probably due to the fact that the children have been filmed in a friendly environment. Yet, in two sequences (one in French, one in English), we can envisage that $\mathrm{Mr}$ Potato Head ${ }^{\mathrm{TM}}$ is an artefact which enables the child to learn about face concerns.

In the French sequence (example 24), there is repair to a potential threat as the child takes her mother's remarks into consideration and gradually changes the unattractive items for goodlooking ones (the relevant passages in the mother's speech are underlined and translated):

(24) moi je trouve que c'est joli

[tu trouves qu'elle est jolie avec une dent toute noire (do you find her beautiful with a black tooth)

oui

[ah bon

et ça ça peut être son nez

[ou sinon y'a une bouche rose (otherwise there is a pink mouth)

oui avec une bouche rose

[ou avec du rouge à lèvres (with lipstick)

mmm non avec une bouche rose ouai regardez

[elle est belle hein (she is beautiful isn't she)

ouai elle est belle hein avec son nez.

lil est un peu gros son nez (her nose is a bit too big)

oh non pas un gros nez on va pas lui est-ce que ca lui va non pas ça on va pas lui mettre ça une casquette et ça c'est des chaussures on dirait

[tu vas pas lui mettre sur la tête des chaussures quand même si (you're not going to put her shoes on her head are you)

non $(\mathrm{M})$

On the contrary, the English mother (example 25) shows her child how to make fun of $\mathrm{Mr}$ Potato Head ${ }^{\mathrm{TM}}$ : she builds Mr Potato's head, in a way that threatens the potato's face:

(25) [that's silly

you made him silly you made him silly mummy

[he was a silly man

he why he (was) a silly man

[because he had all his bits in the wrong places

why

[look he's got a tongue where his what should go there

(laughter) arm

[where his arm should go

(laughter)

[what's that

an ear that the ear place

[that is the ear place oh look he's got two arms on the same side

(laughter)

These examples will be taken up in the Discussion Section (5.). 


\subsection{The interactional dimension}

In the data, we find all types of interaction, as illustrated below. This aspect needs to be further examined, as explained in Section 5.6.

\subsubsection{Humour as response to a previous turn (second turn of an adjacency pair)}

(7) [we can fly together where shall we go

bird road

[bird road (laughter) (HR)

\subsubsection{Humour initiated in a first turn and then found in ensuing responses of both speakers}

(26) they need some medicine isn't there any oh there is some

[(laughter) did it take did th- the cat take his medicine like a good cat

no

[no

he said listen/ XXXX him spit it out

[he spit it out (laughter) oh no you naughty act don't spit out your medicine

why

['cause he won't get better if he spits out his medicine

why

[because you have to take the medicine to m-make to so that it can make you get better if you spit out on the floor

(laughter)

[it won't make you better

(laughter) haha I didn't hear mummy

[if the cat spits his medicine out on the floor

(laughter)

[it can't make him better it has to go in his tummy to make him better

ho mummy

[you naughty cat take your medicine (TD)

In the on-going research which has provided some of the data under study here, we intend to analyze turn-taking thoroughly: this will enable us to describe how speech is co-constructed in the first years after implantation, and to compare the results to the description of speech coconstruction in children with typical development (Pontonx et al. 2017): it will also enable us to analyse more precisely deaf children's development regarding the turn in which humour is initiated and find out if, with time, humour is more frequently initiated by the children.

\section{Discussion of the results and main conclusions}

Our research questions revolved around the fact that the Oral Deaf may share two cultures (deaf and oral cultures); studying their humour seemed therefore likely to provide insight into how they stand culture-wise: do they evidence links with Deaf humour or with humour as practised in the oral language they use? 


\subsection{Deaf experience jokes}

Jokes about experience with deafness are common in the humour of people who sign. To what extent do they occur in our data? In the younger group, several children (example 23) associate magnetic toys to their cochlear implant (cochlear implants include a magnetic part): for them, Deaf experience is a possible topic for humour. There is no such counterpart in the teenagers' data. This is corroborated by our study on euphemism in the Deaf (Vincent-Durroux 2009b) in which we found that for implanted teenagers, deafness is not a topic for euphemism whereas it was the case for teenagers with analog hearing aids. Implanted teenagers seem to have outgrown their Deaf condition and to feel part of the hearing world and culture.

\subsection{The visual dimension}

In sign languages, humour is mostly based on the visual nature of sign languages. To what extent is humour based on visual criteria in our set of data? The visual dimension is pregnant in the younger group, with laughter being triggered when the children build incongruous objects (examples 4 and 21) or when they have objects fall on the floor (examples 6 and 10). It is no longer the case in deaf teenagers. It would probably be the same in hearing subjects with typical development as teenagers don't normally build incongruous objects or have objects fall on the floor. We therefore cannot conclude that the Oral Deaf are specifically sensitive to visual aspects to trigger humour, just as they turn out to be non-specifically visual learners (AuBuchon et al. 2015; Marschark et al. 2015). The visual aspect of humour in sign languages (Sutton-Spence \& Napoli 2012) could well be the expression of proficiency in the language, which happens to be a visual language. Similarly, when Oral Deaf teenagers become more proficient in the spoken language, they produce play-on-words (examples 8 and 9), which implies playing with the features of the spoken form and compares with what Deaf Signers do when their humour is based on "witty reanalysis of existing signs" (see Section 2.3.). Although we have only two examples of play-on-words, they show that the Oral Deaf teenagers access language-related humour in speech (stage 4 in McGhee's stage-model), becoming "mature humorists" (Cunningham 2005: 104).

\subsection{Language-related humour}

The language dimension of humour groups together linguistic play and discursive strategies. We found that discursive strategies are widely used, contrary to linguistic play, although play on the sounds of words appears to be higher for French children than English children (Table 5), fitting the expected trends in French (Table 1). The overall difficulty with linguistic play could be due to the impact of deafness evidenced by Arfé et al. (2015) on high-level linguistic processes in general (humour being one of them) and by Bourdin (2015) on the capacity of linguistic treatment, which was found to be limited in deaf children, with the restricted capacity of their short-term phonological memory as a possible cause. This could impact their phonemic representations of words, and in turn, hinder the possibility of playing on and with words.

\subsection{Target and face concerns}

In our data, humour is rarely self-oriented and recipient-oriented, but almost always third-party oriented. In the younger group it is oriented towards imaginary characters and toys. In the older group, euphemism is to be found about brothers and sisters. This is a common feature with the Signing community who favours third-party oriented humour. Due to the deficit of published research about the targets of humour in hearing children, we cannot say whether this feature in our data is a trend in children in general or if it is deafness-related. 
Yet, differences appear in reference to the language spoken in our oral data: the English speakers threaten the third-party's face more (11 sequences) than the French speakers (5 sequences) (Table 4). Two mothers have remarkable opposite attitudes in their guidance: the French mother gradually convinces her child to change the various parts of Mr Potato's head to make it look less stupid (example 24), whereas the English mother encourages her child to put the various parts in the most stupid manner (example 25). This could be a way for the mothers to train their children into their own speaking community trends as regards face concerns.

\subsection{Main conclusions}

Our main conclusions, based on the most remarkable trends found in the data, are summarized in Table 6. Deaf experience jokes and visual jokes, which are common features between sign language humour and humour in young children with cochlear implants, seem to disappear with time as the child grows. In terms of target, humour is mostly third-party oriented in all sequences, as expected in sign languages and in French; the English speakers would be expected to use more recipient-oriented humour though. As far as the language dimension is concerned, young children with cochlear implants already evidence some of the trends of their respective language (discursive strategies for the English, third-party target for the French); yet the English children almost never use recipient-oriented humour nor threaten the other's face, contrary to what is expected from them. The long sequence in which the English mother does so confirms that it is important in English. The French children and teenagers do not or cannot favour linguistic play as much as would be expected: it may be more difficult for them to access the favourite means of humour in French, i.e. linguistic play, for the reasons mentioned above. On the contrary, the English children access more easily the favourite means of humour in English, i.e. discursive devices, as they are not based on the sounds of the language. 
Table 6. Trends in the Oral Deaf's humour in comparison to trends (filled zones) in sign languages, French and English

\begin{tabular}{|c|c|c|c|}
\hline & $\begin{array}{c}\text { Sign } \\
\text { Language }\end{array}$ & $\begin{array}{l}\text { Spoken } \\
\text { French }\end{array}$ & $\begin{array}{l}\text { Spoken } \\
\text { English }\end{array}$ \\
\hline $\begin{array}{c}\text { Deaf } \\
\text { experience }\end{array}$ & & & \\
\hline Visual jokes & & & \\
\hline $\begin{array}{l}3^{\text {rd }} \text { party } \\
\text { oriented }\end{array}$ & & $\sqrt{ }$ & $\sqrt{ }$ \\
\hline $\begin{array}{l}\text { Recipient- } \\
\text { oriented }\end{array}$ & & & \\
\hline Face threat & & trained not to & trained to \\
\hline$\frac{\text { Linguistic }}{\text { play }}$ & & $\rightarrow$ & \\
\hline$\frac{\text { Discursive }}{\text { devices }}$ & & $\sqrt{ }$ & $\sqrt{ }$ \\
\hline
\end{tabular}

Colour code: blue $=$ French Oral Deaf $;$ brown $=$ English Oral Deaf Symbols: $\sqrt{ }=$ trend found in the data; $\not=$ trend not found in the data; $\longrightarrow=$ tendency to decrease over time; $\boldsymbol{\nabla}=$ tendency to increase over time

\subsection{Limitations and further steps}

It is important to interpret the results with caution, due to the small sample size and the qualitative approach favoured in this study, but also to the fact that the tasks had to be adapted to the different age groups, leading to possible variation in humour expression. Furthermore, the data was collected over several years: the quality of cochlear implants has improved over time, possibly changing the perception of the participants. Yet, this limitation is to be found in any on-going research in this domain. In order to be more assertive about the trends mentioned above, it would be interesting to examine humour in Deaf adults fitted with cochlear implants from an early age. Unfortunately for the time being, early implantation within the phonological critical period (i.e. before 12 months of chronological age) is too recent a practice to allow this. Further research involving more subjects over a longer period of time should also be undertaken, especially until the subjects reach adulthood. In the on-going research which has provided some of the data under study here, we intend to analyze turn-taking thoroughly: this will enable us to describe how speech is co-constructed in the first years after implantation, and to compare the results to the description of speech co-construction in children with typical development (Pontonx et al. 2017): it will also enable us to analyse more precisely deaf children's development regarding the turn in which humour is initiated and find out if, with time, humour is more frequently initiated by the children. 


\section{Acknowledgements}

The author would like to acknowledge the helpful comments and suggestions made by the reviewers, and wishes to thank the children and teenagers who took part to this study, as well as their parents and the institutions where the recordings were made: The Elizabeth Foundation in Cosham (U.K.) and Institut Saint-Pierre in Palavas (France).

\section{References}

Arfé, B., Rossi, C. \& Sicoli, S. (2015). 'The contribution of verbal working memory to deaf children's oral and written production'. Journal of Deaf Studies and Deaf Education 20 (3), pp. 203-214.

AuBuchon, A.M., Pisoni, D.B. \& Kronenberger, W.G. (2015). 'Verbal processing speed and executive functioning in long-term cochlear implant users'. Journal of Speech, Language, and Hearing Research 58, pp. 151-162.

Béal, C. (2010). Les interactions quotidiennes en français et en anglais. De l'approche comparative à l'analyse des situations interculturelles. Bern: Peter Lang, Linguistics Insights, Studies in Language and Communication 99.

Béal, C. \& Mullan, K. (2017). 'The pragmatics of conversational humour in social visits: French and Australian English'. Language \& Communication 55, pp. 24-40.

Béal, C. \& Mullan, K. (2013). 'Issues in conversational humour from a cross-cultural perspective: comparing French and Australian corpora', in Peeters, B., Mullan, K. and Béal, C. (eds), Cross-culturally Speaking, Speaking Cross-culturally, Cambridge Scholars Publishing.

Bienvenu, M. J. (1994). 'Reflections of deaf culture in deaf humour', in Erting, C., Johnson, R., Smith, D. \& Snider, B. (eds), The Deaf Way, Washington DC: Gallaudet University Press, pp. 16-23.

Bourdin, B. (2015). 'Un modèle capacitaire du traitement langagier chez l'enfant sourd : le cas de la morphosyntaxe'. ANAE 138, Approche neuropsychologique des apprentissages chez l'enfant, Surdité : évolutions technologiques, de la prise en charge et des apprentissages, pp. 469-476.

Cancio-Bello, E. (2015). The Sources of Deaf Humor. An Exploration of the Reasons Deaf Humor Differs from That of Hearing People. Bachelor thesis in the Department of Linguistics Swarthmore College Swarthmore (Pennsylvania). Advisor: Ted Fernald.

Charaudeau, P. \& Maingueneau, D. (2002). Dictionnaire d'analyse du discours. Paris : Le Seuil.

Charaudeau, P. (2006). 'Des catégories pour l'humour?'. Questions de communication, Available: http://questionsdecommunication.revues.org/7688. Accessed 23 November 2020.

Charrow, V.R. (1975). 'A psycholinguistic analysis of Deaf English'. Sign Language Studies 7, pp. 139-150.

Cunningham, J. (2006). 'Children's humour', in Scarlett W. G., Al-Solaim, L., Naudeau, S., Salonius-Pasternak, D. \& Ponte, I. (eds.), Children's Play, chapter 5, SAGE Publications: Thousand Oaks CA, London, New Delhi, pp. 93-109.

Del Ré, A., Dodane, C. \& Morgenstern, A. (2015). 'De l'amusement partagé à la production de l'humour chez l'enfant', in Farhat, M. \& Lacoste, F. (eds). L'Humour dans le bassin méditerranéen, Sfax: Nouha Editions, pp. 115-139.

Del Ré, A., Dodane, C., Vieira, A., Leroy-Collombel, M. \& Morgenstern, A. (this volume). 'Children's development of humor in everyday interactions: two case-studies in French and Brazilian Portuguese'. 
Duchesne, L., Sutton, A. \& Bergeron, F. (2009). 'Language achievement in children who received cochlear implants between 1 and 2 years of age: Group trends and individual patterns'. Journal of Deaf Studies and Deaf Education 14 (4), pp. 465-485.

Dutilleul-Guerroudj, E. (2005). Catégorisation linguistique et surdité de l'enfant. Comment l'enfant sourd construit du sens dans le langage oral. Ph.D. dissertation in linguistics, University Montpellier 3.

Hallé, F. \& Duchesne, L. (2015). 'Habiletés morpho-syntaxiques des enfants sourds porteurs d'implants cochléaires : une revue systématique'. Revue canadienne d'orthophonie et d'audiologie 39 (3), pp. 260-297.

Holmes, J. \& Marra, M. (2002). 'Over the edge? Subversive humor between colleagues and friends'. Humor: International Journal of Humor Research 15 (1), pp. 65-87.

Horejes, T. D. (2012). Social Constructions of Deafness: Examining Deaf Languacultures in Education. Washington, DC: Gallaudet University Press.

Lacerte, L. (1988). La langue des signes québécoise (L.S.Q.) et le français : difficultés à l'écrit chez la personne sourde. MA thesis. Montreal: Université du Québec à Montréal.

Leigh, I. W., Andrews, J. F., Harris, R. L. (2018). Deaf Culture: Exploring Deaf Communities in the United States. San Diego, CA: Plural Publishing.

McGhee, P. E. (1979). Humor: Its Origin and Development. San Francisco, CA: Freeman.

McGhee, P. E. (2002). Understanding and Promoting the Development of Children's Humor. Kendall/Hunt.

Makagon, M. M., Sumie Funayama, E. \& Owren M. J. (2008). 'An acoustic analysis of laughter produced by congenitally deaf and normally hearing college students'. The Journal of the Acoustical Society of America 124 (1), pp. 472-483.

Marschark, M., Spencer, L., Durkin, A., Borgna, G., Convertino, C., Machmer, E., Kronenberger, W. G. \& Trani, A. (2015). 'Understanding language, hearing status, and visual-spatial skills'. The Journal of Deaf Studies and Deaf Education 20 (4), pp. 310-330.

Marschark, M., Duchesne, L. \& Pisoni, D. (to appear). 'Effects of age of cochlear implantation on learning and cognition: a critical assessment'.

Morgenstern, A \& Parisse, C. (eds.) (2017). Le Langage de l'Enfant. De l'Eclosion à l'Explosion. Paris: Presses de la Sorbonne Nouvelle. Available: http://psn.univparis3.fr/ouvrage/le-langage-de-lenfant-de-leclosion-lexplosion. Accessed 23 November 2020.

Mullan, K. \& Béal, C. (2018). 'Conversational humour in French and Australian English: What makes an utterance (un)funny?'. Special Issue: Conversational humor: Forms, functions and practices across cultures. Intercultural Pragmatics 15 (4), pp. 457-485.

Nwokah E. E., Burnette S. E. \& Graves K. N. (2013). 'Joke telling, humor creation, and humor recall in children with and without hearing loss'. Humor: International Journal of Humor Research 26 (1), pp. 69-96.

Partington, A. (2006). The Linguistics of Laughter: A Corpus-assisted Study of Laughter-talk. New York: Routledge.

Pontonx, S. de, Leroy-Collombel, M., Masson, C. \& Morgenstern, A. (2017). 'Transmission et élaboration du langage dans le dialogue', in Morgenstern, A. \& Parisse, C. (eds.). Le langage de l'enfant. De l'éclosion à l'explosion, Paris : Presses de la Sorbonne Nouvelle, pp. 27-40.

Provine, R.R. \& Fischer, K.R. (1989). 'Laughing, smiling and talking: Relation to sleeping and social context in humans'. Ethology 83, pp. 295-305.

Sanders, D. M. (1986). 'Sign language in the production \& appreciation of humor by deaf children'. Sign Language Studies 50, pp. 59-72.

Sutton-Spence, R. \& Napoli, D. J. (2009). Humor in Sign Languages: The Linguistic Underpinnings. Dublin: Centre for Deaf Studies at Trinity College Dublin. 
Sutton-Spence, R. \& Napoli, D. J. (2012). 'Deaf jokes and sign language humor'. Humor: International Journal of Humor Research 25 (3), pp. 311-337.

Tomasello, M. (2003). Constructing a Language. A Usage-based Theory of Language Acquisition. Cambridge Mass. \& London: Harvard University Press.

Vincent-Durroux, L. (1992). La langue orale des sourds profonds oralistes. Etude comparative (anglais / français). Ph.D. dissertation in linguistics. Paris : Université de la Sorbonne.

Vincent-Durroux, L. (2009a). 'Deaf languages: does the hypothesis still apply?'. Corela (Cognition, représentation, langage) 7 (2). Available: http://edel.univpoitiers.fr/corela/document.php?id=2244. Accessed 15 May 2019.

Vincent-Durroux, L. (2009b). 'Modalités des euphémismes dans le discours oral de locuteurs sourds profonds anglophones et francophones', in Jamet, D. \& Jobert, M. (eds.). Empreintes de l'euphémisme. Tours et détours, Paris : L'Harmattan, pp. 69-82

Vincent-Durroux, L. (2014). La langue orale des jeunes sourds profonds. Paris: De BoeckSolal, collection Voix Parole Langage.

Vrticka, P., Black, J. M. \& Reiss, A. L. (2015). 'The neural basis of humour processing'. Nature reviews. Neuroscience. MacMillan Publishers Ltd, pp. 1-9. 